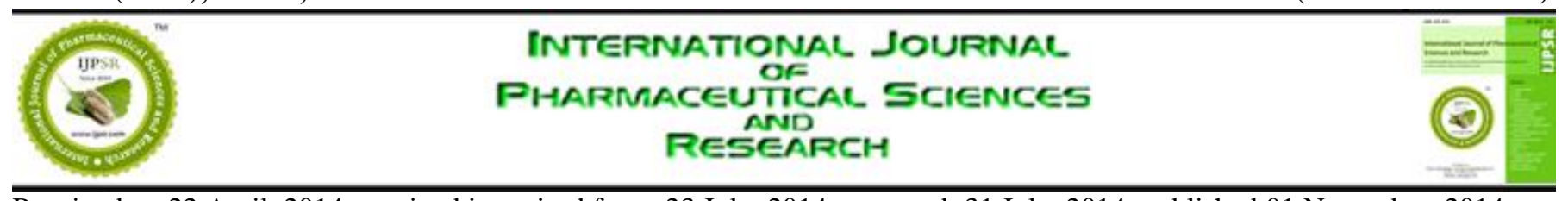

Received on 22 April, 2014; received in revised form, 23 July, 2014; accepted, 31 July, 2014; published 01 November, 2014

\title{
A VALIDATED RP-HPLC METHOD FOR SIMULTANEOUS ESTIMATION OF ASPIRIN AND PRASUGREL IN TABLET DOSAGE FORM
}

P. Vivek Sagar ${ }^{* 1}$, T. Samidha ${ }^{1}$, M. Vamshi Krishna ${ }^{1}$ and S. Shobha Rani ${ }^{2}$

Department of Pharmaceutical Analysis, Care College of pharmacy ${ }^{1}$, Oglapur (v), Atmakur (M), Warangal, Telangana, India.

Department of Pharmaceutical Analysis, Jawaharlal Nehru Technological University ${ }^{2}$, Kukatpally, Hyderabad, Telangana, India.

Keywords:

Aspirin, Prasugrel, RP- HPLC, Validation

Correspondence to Author:

P. Vivek Sagar

Care College of Pharmacy

Oglapur (v), Atmakur (M),

Warangal, Telangana, India

E-mail: viveksagar.p111@gmail.com

\begin{abstract}
Aim of the present work is to develop a rapid, simple, precise, accurate and reproducible reverse phase high performance liquid chromatographic method for simultaneous determination of Aspirin and Prasugrel in tablet dosage form. The estimation was carried out on a HIBAR (Lichrospher C-18) column with the dimensions of $250 \mathrm{~mm} \times 4.6 \mathrm{~mm}, 5 \mu \mathrm{m}$. Combination of Acetonitrile and $0.5 \%$ Potassium dihydrogen phosphate buffer (adjusted to $\mathrm{pH}-3$ using orthophosphoric acid) in the ratio of 60: 40 was used as mobile phase. The flow rate is set at $1.0 \mathrm{ml} / \mathrm{min}$ and eluents were monitored at $220 \mathrm{~nm}$. Both drugs were properly resolved having run time of $3.3 \mathrm{~min}$ and $4.8 \mathrm{~min}$ for Aspirin and Prasugrel, respectively. The method was validated as a final verification of method development with respect to Precision, Linearity, Accuracy, Ruggedness and Robustness. Linearity for Aspirin and Prasugrel was in the range of $10-450 \mu \mathrm{g} / \mathrm{ml}$ and $10-500 \mu \mathrm{g} / \mathrm{ml}$ respectively. The mean recoveries obtained for Aspirin and Prasugrel were within the range of $98-102 \%$.
\end{abstract}

INTRODUCTION: Aspirin (ASP), 2-acetoxy benzoic acid is cyclooxygenase inhibitor. The molecular formula is $\mathrm{C} 9 \mathrm{H} 8 \mathrm{O} 4$ and the molecular weight is $180.16 \mathrm{gm} / \mathrm{mole}$. It is a Non-steroidal Anti-inflammatory drug and inhibits Platelet aggregation. Prasugrel chemically is 5-[2cyclopropyl-1-(2-fluorophenyl)-2-oxoethyl]-4, 5, 6, 7-tetrahydrothienol [3, 2- c] pyridin-2-ylacetate. The molecular formula is C20H20FNO3Sand the molecular weight is $373.442 \mathrm{gm} / \mathrm{mole}$.

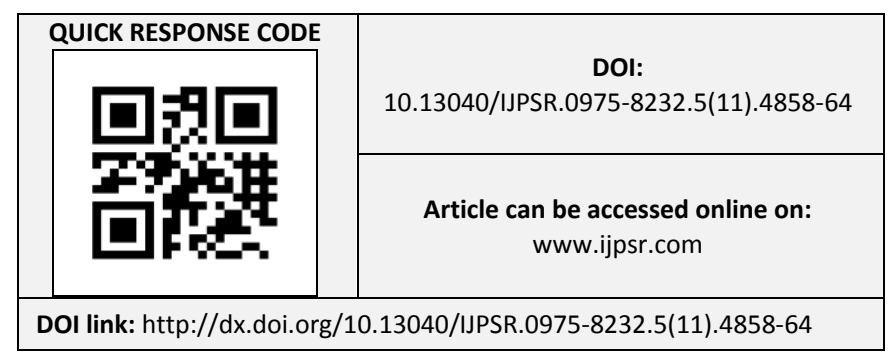

International Journal of Pharmaceutical Sciences and Research
It inhibits adenosine diphosphate induced platelet aggregation and used in the treatment of coronary artery disease. Structures for aspirin and Prasugrel were given in Figures 1 and 2.

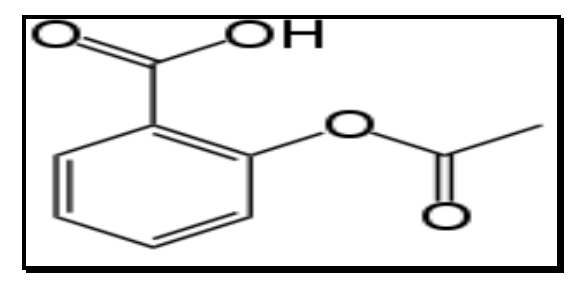

FIGURE 1.STRUCTURE OF ASPIRIN

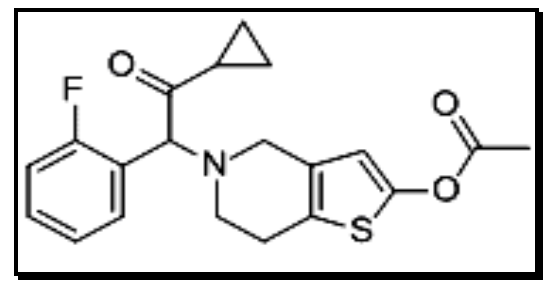

FIGURE 2.STRUCTURE OF PRASUGREL 
Literature survey revealed that only few analytical methods (3-18) such as HPLC, LC-MS, UV, and HPTLC have been reported for the determination of PRASU and ASP individually and in combination with other drugs. Only two methods (1-2) were reported till date using RP-HPLC which suffers with some drawbacks like high retention time, asymmetric peak shape and low range of linearity. The present study focuses on development of simple, rapid, sensitive, precise, accurate and cost effective analytical method for estimation of Aspirin and Prasugrel in Tablet dosage form.

\section{MATERIALS AND METHODS:}

\section{Reagents and chemicals:}

The bulk drug of Prasugrel was obtained as a gift sample from MSN Laboratories, Hyderabad. HPLC grade Acetonitrile, Orthophosphoric acid and Potassium dihydrogen phosphate, sodium hydroxide were obtained from Merck and Milli-Q water of HPLC grade was used for the experiment.

\section{Stock solution and standards:}

$25 \mathrm{mg}$ of Aspirin and Prasugrel were accurately weighed and transferred in to a $25 \mathrm{ml}$ volumetric flask and required quantity of mobile phase was added to dissolve the drugs. Then volume was made up to the mark with mobile phase. This gives the standard stock solution of Aspirin and Prasugrel having concentration of $1000 \mu \mathrm{g} / \mathrm{ml}$. working standard solutions were prepared by transferring suitable aliquots of standard solution in to $10 \mathrm{ml}$ volumetric flask and made up to mark with mobile phase.

\section{Apparatus and Chromatographic conditions:}

HPLC analysis was performed on SHIMADZU 20AD HPLC outfitted with dual head reciprocating pump with a manually operating Rheodyne injector of $20 \mu \mathrm{l}$ sample loop and a SPD-20A UV-Vis detector. The software equipped was LC solution software. The Chromatographic column,

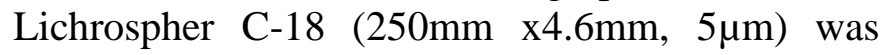
used as a stationary phase. Acetonitrile and $0.5 \%$ potassium dihydrogen phosphate $(\mathrm{pH}-3)$ in the ratio of 60:40 was used as mobile phase. The pump flow rate was set at $1.0 \mathrm{ml} / \mathrm{min}$. The eluent was detected at $220 \mathrm{~nm}$ and run time was $7 \mathrm{~min}$.

\section{Preparation of sample solution:}

Twenty tablets were weighed accurately and crushed to form a fine powder. Accurately weighed quantity of powder equivalent to $75 \mathrm{mg}$ of Aspirin, and 10mg of Prasugrel were transferred in to a 100 $\mathrm{ml}$ of volumetric flask, $50 \mathrm{ml}$ of mobile phase was added.

The volume was made up to mark with mobile phase and then sonicated for $5 \mathrm{~min}$. This solution was then filtered through whatmann filter paper. Suitable aliquot of the filtrate was pipetted in to $10 \mathrm{ml}$ volumetric flask and volume made up with mobile phase to obtain concentration in the range of linearity previously determined. This solution was filtered through a $0.45 \mu$ membrane filter and sonicated for $2 \mathrm{~min}$. This was marked as Test solution.

TABLE.1. SYSTEM SUITABILITY DATA FOR ASPIRIN AND PRASUGREL

\begin{tabular}{lll}
\hline $\begin{array}{l}\text { System suitability } \\
\text { Parameters }\end{array}$ & Aspirin & Prasugrel \\
\hline Retention time (Rt) & 3.364 & 4.832 \\
Peak area & 2239644 & 1823730 \\
USP plate count (N) & 6978.447 & 7719.533 \\
USP tailing factor (T) & 1.2545 & 1.321833 \\
Resolution factor (Rs) & 8.404 & 7.670 \\
$\begin{array}{l}\text { Relative retention time } \\
\text { RRT) }\end{array}$ & 0 & 1.468 \\
$\%$ RSD of(n=6) & & \\
\hline
\end{tabular}

\section{Assay of Marketed Formulation:}

Prepared sample solution was injected under identical chromatographic conditions as mentioned earlier and chromatograms were recorded. This was done in triplicate. The amount of Aspirin and Prasugrel is calculated from the calibration curve. The results were given in the Table 2 . Representative chromatograms for blank, standard and sample were given in the Figures 5, 6 \&7.

TABLE.2. ASSAY DATA FOR ASPIRIN AND PRASUGREL TABLET FORMULATION

\begin{tabular}{lll}
\hline Parameter & Aspirin & Prasugrel \\
\hline \multirow{2}{*}{ Peak areas } & 18728452 & 2044350 \\
& 18725699 & 2053678 \\
& 18789989 & 2043645 \\
\hline Mean & 18728937 & 2043671 \\
\hline \% Assay & $99.8 \%$ & $100.07 \%$ \\
\hline
\end{tabular}




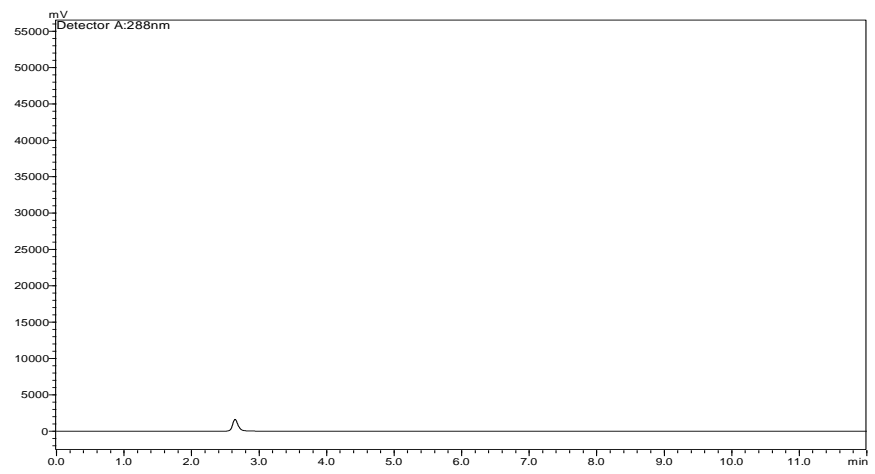

FIGURE 5. CHROMATOGRAM OF BLANK

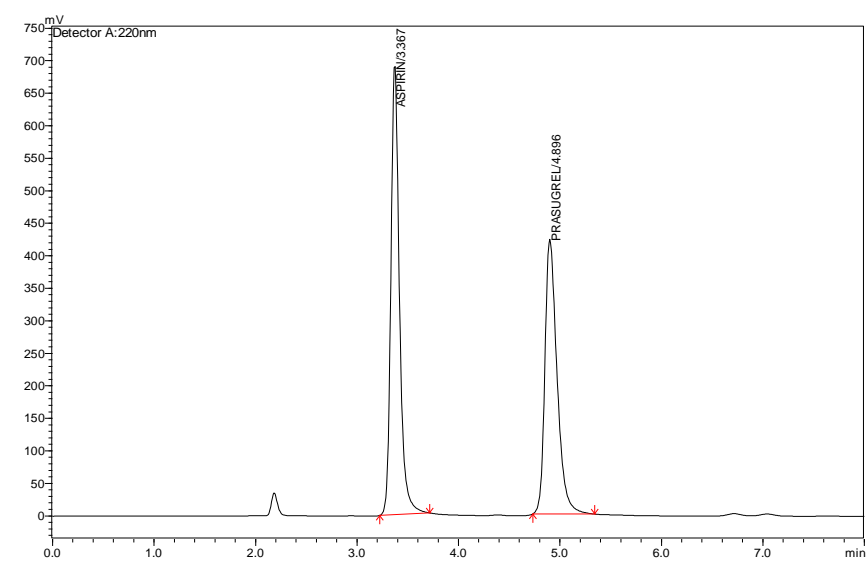

FIGURE 6. CHROMATOGRAM OF STANDARD MIXTURE

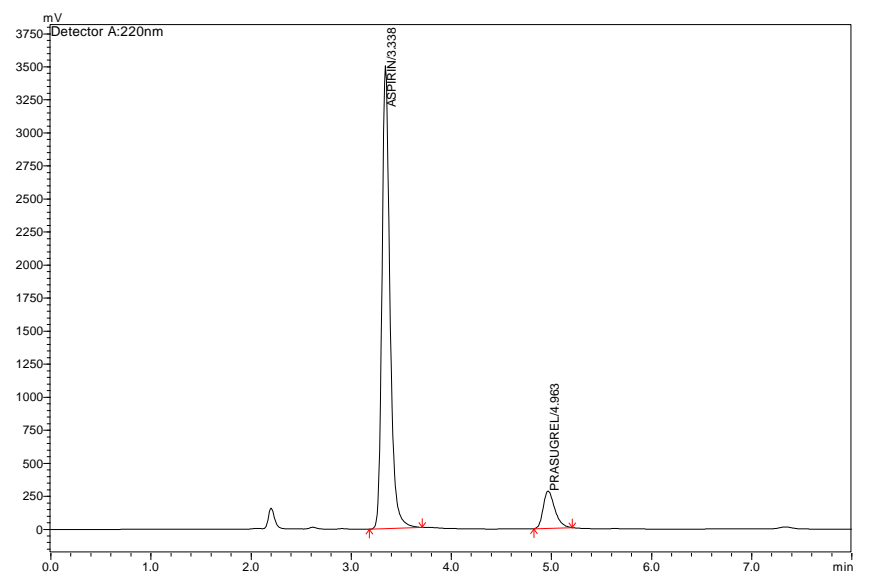

FIGURE 7. CHROMATOGRAM OF TEST FORMULATION

Validation of Assay Method:

\section{Linearity:}

Linearity of the method was demonstrated over wide concentration ranges of Aspirin and Prasugrel. Each concentration was determined in duplicate. $20 \mu 1$ of each of standard solutions were injected at the optimized chromatographic conditions and the chromatograms were recorded. The average peak areas were noted. Calibration curve for ASP and PRASU were constructed by plotting concentration on $\mathrm{X}$-axis against mean peak area on Y-axis and regression equation was calculated by the method of least squares. The correlation coefficient, y-intercept, slope of the regression line were noted.

\section{Recovery and Accuracy:}

Accuracy of the method was established by performing recovery studies.It was ascertained on the basis of recovery studies by standard addition method. Recovery studies were carried out at five different levels $(25 \%, 50 \%, 75 \%, 100 \%$, and $125 \%$ ) by the addition of standard drug to preanalyzed sample solution having the concentration of $75 \mu \mathrm{g} / \mathrm{ml}$ of Aspirin and $10 \mu \mathrm{g} / \mathrm{ml}$ of Prasugrel. Triplicate determinations were carried out at each level. Mean percentage recovery values at five different levels of the two drugs were calculated.

\section{Precision:}

Precision was carried out at two levels i.e. repeatability of injections and intermediate precision.

Repeatability also called intra assay precision assessed by using a minimum of 9 determinations (3 concentrations/ 3 replicates). It was carried out at three different levels i.e. $50 \%, 100 \%$ and $150 \%$ under specified chromatographic conditions. $20 \mu 1$ of each level was injected in triplicate.

Intermediate precision expresses the precision within laboratory variations. It includes full analysis on different days, instruments or analysts. It was performed using standard concentration of $100 \mu \mathrm{g} / \mathrm{ml}$.

\section{Robustness:}

To evaluate the robustness of the developed RPHPLC method, small deliberate variations in the optimized chromatographic conditions were done i.e. variation in flow rates $( \pm 0.1 \mathrm{ml} / \mathrm{min})$, concentration of organic phase $( \pm .2 \%)$ and detection wavelengths $( \pm 3 \mathrm{~nm})$. It was performed using $50 \mu \mathrm{g} / \mathrm{ml}$.

\section{RESULTS:}

Method development and optimization:

To develop a suitable HPLC method for the determination of Aspirin and Prasugrel, trials were performed with different mobile phases, using 
water and acetonitrile at different $\mathrm{pH}$ with different compositions of mobile phases like 50:50 (water: Acetonitrile $\mathrm{pH}-3), \quad 50: 50 \quad(0.5 \%$ potassium dihydrogen phosphate buffer: Acetonitrile $\mathrm{pH}-3$ ), 60:40 (Acetonitrile: 0.5\% potassium dihydrogen phosphate $\mathrm{pH}-3$ and also by changing different columns like YMC ODS column and HIBAR (Lichrospher) column. The method was optimized finally using combination of Acetonitrile and $0.5 \%$ potassium dihydrogen phosphate buffer $\mathrm{pH}-3$ in the ratio of $60 / 40 \mathrm{v} / \mathrm{v}$ with a flow rate of $1.0 \mathrm{ml} / \mathrm{min}$. The drugs were eluted at retention times of 3.3 minutes for Aspirin and 4.8 minutes for Prasugrel at a detection wavelength of $220 \mathrm{~nm}$. The run time was set for 7 minutes.

\section{Validation:}

\section{Linearity:}

Calibration curves were constructed by plotting concentration on $\mathrm{X}$-axis against average peak area on $\mathrm{Y}$-axis and regression equations were computed. Linearity was established over the concentration range of $10-450 \mu \mathrm{g} / \mathrm{ml}$ for Aspirin and $10-500 \mu \mathrm{g} / \mathrm{ml}$ for Prasugrel. Correlation coefficient for Aspirin and Prasugrel was found to be 0.999 and 0.9991 respectively. The results were given in the Table 3 . Plot was given in Figures 3\& 4

TABLE.3. LINEARITY DATA FOR ASPIRIN AND PRASUGREL

\begin{tabular}{|c|c|c|c|}
\hline \multirow{2}{*}{ S. no } & \multirow{2}{*}{$\begin{array}{l}\text { Concentrati } \\
\text { on }(\mu \mathrm{g} / \mathrm{ml})\end{array}$} & \multicolumn{2}{|c|}{ Mean peak area } \\
\hline & & Aspirin & Prasugrel \\
\hline 1 & 10 & 540423 & 44806 \\
\hline 2 & 50 & 2237906 & 1943761 \\
\hline 3 & 100 & 4513697 & 3802566 \\
\hline 4 & 150 & 6561985 & 5600155 \\
\hline 5 & 200 & 8983334 & 7290167 \\
\hline 6 & 250 & 11201618 & 9079435 \\
\hline 7 & 300 & 13874744 & 10968055 \\
\hline 8 & 350 & 16086881 & 13281506 \\
\hline 9 & 400 & 18428937 & 15258892 \\
\hline 10 & 450 & 21266874 & 16651972 \\
\hline 11 & 500 & - & 18529591 \\
\hline
\end{tabular}

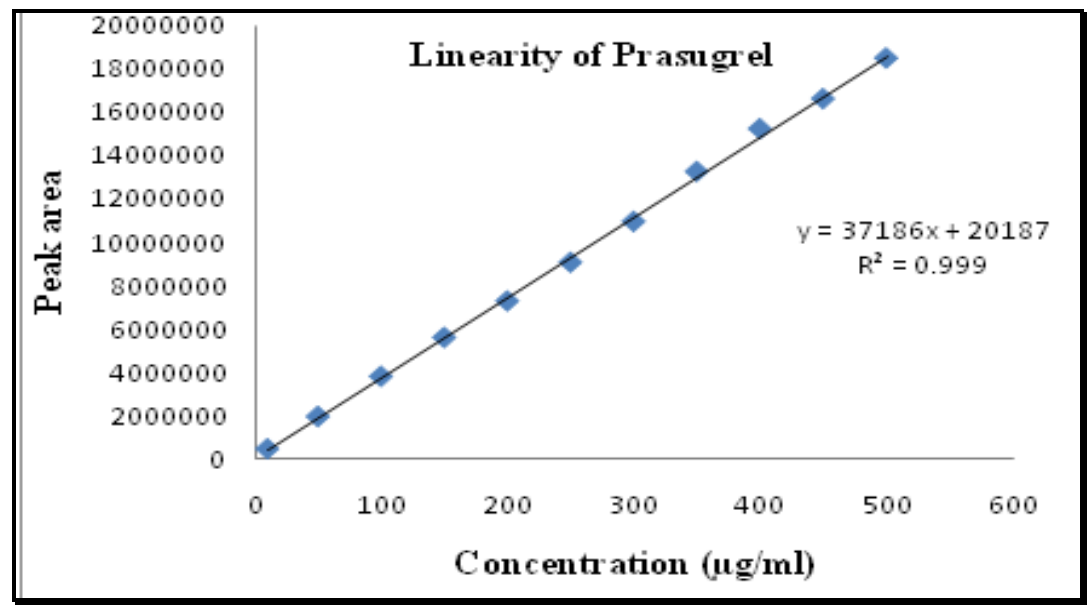

FIGURE 3. CALIBRATION CURVE FOR ASPIRIN

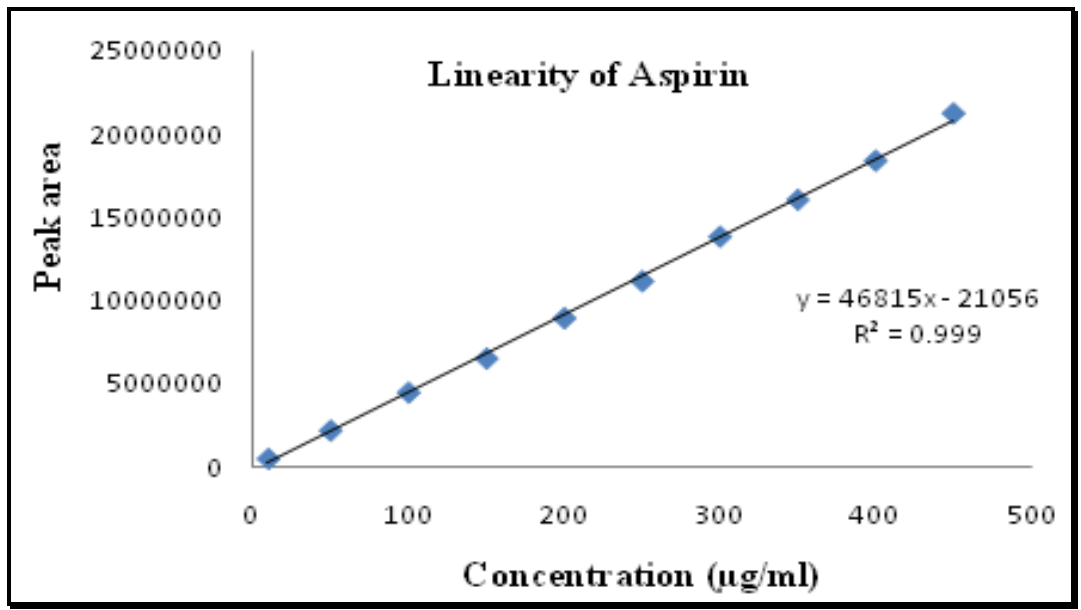

FIGURE 4. CALIBRATION CURVE FOR PRASUGREL 


\section{Recovery and Accuracy:}

The $\%$ recoveries of Aspirin and Prasugrel at each level was within the limits of $98 \%$ and $102 \%$ given in the Table.7.0 which indicates that the method was accurate and also reveals that the excepients present in the pharmaceutical formulation has no interference with the analytes. The results were given in the Table.4.

TABLE.4. ACCURACY STUDY DATA FOR ASPIRIN AND PRASUGREL

\begin{tabular}{|c|c|c|c|c|c|c|}
\hline \multirow[b]{2}{*}{ \% Level } & \multicolumn{3}{|l|}{ Aspirin } & \multicolumn{3}{|l|}{ Prasugrel } \\
\hline & $\begin{array}{l}\text { Amount of } \\
\text { drug added } \\
(\mu \mathrm{g} / \mathrm{ml})\end{array}$ & $\begin{array}{l}\text { Amount of } \\
\text { drug } \\
\text { recovered } \\
(\mu \mathrm{g} / \mathrm{ml})\end{array}$ & $\begin{array}{l}\text { Average \% } \\
\text { Recovery }\end{array}$ & $\begin{array}{l}\text { Amount of } \\
\text { drug added } \\
(\mu \mathrm{g} / \mathrm{ml})\end{array}$ & $\begin{array}{l}\text { Amount of } \\
\text { drug } \\
\text { recovered } \\
(\mu \mathrm{g} / \mathrm{ml})\end{array}$ & Average \% Recovery \\
\hline $50 \%$ & 175 & 173.04 & 98.8 & 110 & 109.6 & 99.6 \\
\hline $75 \%$ & 225 & 225.5 & 100.2 & 160 & 162 & 101.8 \\
\hline $100 \%$ & 275 & 274.3 & 99.7 & 210 & 206.11 & 98 \\
\hline $125 \%$ & 325 & 327.9 & 100.8 & 260 & 260.5 & 100.1 \\
\hline $150 \%$ & 375 & 377.4 & 100.64 & 310 & 311.2 & 100.3 \\
\hline
\end{tabular}

\section{Precision:}

From the precision studies, it is evident that \%RSD of the peak areas and \%assay of both the drugs were below $2.0 \%$. Thus, Precision was established. Hence, the developed method was precise. The results were given in the Table. 5, 6 and 7.

TABLE.5. INTRA-ASSAY PRECISION DATA FOR ASPIRIN AND PRASUGREL

\begin{tabular}{|c|c|c|c|c|}
\hline \multirow[b]{2}{*}{ Level } & \multicolumn{2}{|l|}{ Aspirin } & \multicolumn{2}{|l|}{ Prasugrel } \\
\hline & $\begin{array}{l}\text { Peak } \\
\text { area }\end{array}$ & $\begin{array}{l}\text { Mean\% } \\
\text { Recovery }\end{array}$ & Peak area & $\begin{array}{l}\text { Mean \% } \\
\text { Recovery }\end{array}$ \\
\hline \multirow{4}{*}{$50 \%$} & 6463961 & & 5658792 & \\
\hline & 6775570 & 100.2 & 5668986 & 100.77 \\
\hline & 6482397 & & 5656453 & \\
\hline & 13874744 & & 10968055 & \\
\hline \multirow[t]{3}{*}{$100 \%$} & 13684218 & 100.2 & 10905785 & 99.21 \\
\hline & 13998756 & & 10998172 & \\
\hline & 21465872 & & 16249690 & \\
\hline \multirow[t]{3}{*}{$150 \%$} & 21266874 & 100.06 & 16651972 & 100.2 \\
\hline & 21384968 & & 16622401 & \\
\hline & \%RSD & 0.22 & $\%$ RSD & 0.78 \\
\hline
\end{tabular}

TABLE.6.INTERMEDIATE PRECISION DATA FOR ASPIRIN AND PRASUGREL $(100 \mu \mathrm{g} / \mathrm{ml})$

\begin{tabular}{|c|c|c|c|c|c|c|c|c|}
\hline \multirow{3}{*}{ Injections } & \multicolumn{4}{|l|}{ Analyst-1 } & \multicolumn{4}{|l|}{ Analyst-2 } \\
\hline & \multicolumn{2}{|l|}{ Aspirin } & \multicolumn{2}{|l|}{ prasugrel } & \multicolumn{2}{|l|}{ Aspirin } & \multicolumn{2}{|l|}{ Prasugrel } \\
\hline & Peak area & $\begin{array}{l}\% \\
\text { Assay }\end{array}$ & Peak area & $\begin{array}{l}\% \\
\text { Assay }\end{array}$ & Peak area & $\begin{array}{l}\% \\
\text { Assay }\end{array}$ & Peak area & $\begin{array}{l}\text { \% } \\
\text { Assay }\end{array}$ \\
\hline 1 & 9817463 & 100.4 & 8293594 & 100.01 & 9776097 & 100.3 & 8220780 & 99.6 \\
\hline 2 & 9688320 & 99.1 & 8278922 & 99.29 & 9706201 & 100.3 & 8294586 & 100.5 \\
\hline 3 & 9773676 & 99.98 & 8318031 & 99.8 & 9762541 & 100.8 & 8256147 & 100.1 \\
\hline 4 & 9733951 & 99.5 & 8232632 & 99.3 & 9715049 & 99.8 & 8234500 & 99.8 \\
\hline 5 & 9848547 & 100.7 & 8203431 & 99.0 & 9685431 & 99.4 & 8245341 & 99.9 \\
\hline 6 & 9821360 & 100.4 & 8284986 & 99.4 & 9724048 & 100.4 & 8232186 & 99.8 \\
\hline \multicolumn{2}{|c|}{$\%$ RSD } & 0.61 & $\%$ RSD & 0.37 & $\%$ RSD & 0.49 & $\%$ RSD & 0.31 \\
\hline
\end{tabular}

\section{Robustness:}

Even though by inducing variations in mobile phase composition, detection wavelength and flow rate, \%RSD of the peak areas of Aspirin and
Prasugrel was not more than $2.0 \%$ Hence, the analytical method is robust and is unaffected by small deliberate variations in the method parameters. The results were given in the Table.8. 
TABLE.7. INTERMEDIATE PRECISION DATA FOR ASPIRIN AND PRASUGREL $(100 \mu \mathrm{g} / \mathrm{ml})$

\begin{tabular}{lllllllll}
\hline Injections & Day-1 & \multicolumn{3}{c}{ Day -2 } \\
\cline { 2 - 9 } & $\begin{array}{l}\text { Aspirin } \\
\text { Peak area }\end{array}$ & $\begin{array}{l}\text { \% } \\
\text { Assay }\end{array}$ & $\begin{array}{l}\text { prasugrel } \\
\text { Peak area }\end{array}$ & $\begin{array}{l}\text { \% } \\
\text { Assay }\end{array}$ & $\begin{array}{l}\text { Aspirin } \\
\text { Peak area }\end{array}$ & $\begin{array}{l}\text { \% } \\
\text { Assay }\end{array}$ & $\begin{array}{l}\text { Prasugrel } \\
\text { Peak area }\end{array}$ & \% Assay \\
\hline 1 & 4503473 & 100.6 & 3726300 & 99.64 & 4455543 & 99.6 & 3708188 & 99.1 \\
2 & 4473439 & 100.05 & 3709073 & 99.20 & 4426736 & 99.0 & 3756872 & 100.4 \\
3 & 4458529 & 99.73 & 3749114 & 100.2 & 4455642 & 99.6 & 3728482 & 99.7 \\
4 & 4464748 & 99.86 & 3758249 & 100.5 & 4446495 & 99.4 & 3760791 & 100.5 \\
5 & 4485174 & 100.3 & 3715630 & 99.3 & 4482657 & 100.2 & 3726732 & 99.6 \\
6 & 4496958 & 100.5 & 3733257 & 99.8 & 4477316 & 100.1 & 3748975 & 100.2 \\
& \%RSD & 0.35 & \%RSD & 0.5 & \%RSD & 0.44 & \%RSD & 0.54 \\
\hline
\end{tabular}

TABLE.8. ROBUSTNESS DATA FOR ASPIRIN AND PRASUGREL

\begin{tabular}{lcllllll}
\hline \multirow{2}{*}{ Parameter } & variation & $\begin{array}{l}\text { Mean } \\
\text { Rt }\end{array}$ & $\begin{array}{l}\text { Mean Peak } \\
\text { Area }\end{array}$ & $\begin{array}{l}\text { \% RSD } \\
\text { of Peak } \\
\text { Areas }\end{array}$ & $\begin{array}{l}\text { Mean } \\
\text { Rt }\end{array}$ & $\begin{array}{l}\text { Mean Peak } \\
\text { Area }\end{array}$ & $\begin{array}{l}\text { \% RSD } \\
\text { of Peak } \\
\text { Areas }\end{array}$ \\
\cline { 2 - 7 } Flow rate & 0.9 & 3.741 & 2443361 & 1.84 & 5.065 & 1868508 & 1.02 \\
(ml/min) & 1.0 & 3.386 & 2439364 & 0.93 & 4.835 & 1851181 & 0.71 \\
& 1.1 & 3.078 & 2466633 & 0.76 & 4.164 & 1863090 & 1.31 \\
& $217 \mathrm{~nm}$ & 3.366 & 1938318 & 1.63 & 4.861 & 1668374 & 1.27 \\
Wavelength & $220 \mathrm{~nm}$ & 3.384 & 2420403 & 1.20 & 4.848 & 1851181 & 0.71 \\
& $223 \mathrm{~nm}$ & 3.375 & 2036054 & 1.37 & 4.870 & 1443889 & 1.58 \\
Mobile Phase & $58: 42$ & 3.374 & 2477220 & 0.92 & 5.065 & 1857684 & 1.32 \\
(ACN: Buffer) & $60: 40$ & 3.386 & 2439364 & 0.93 & 4.835 & 1851181 & 0.71 \\
& $62: 38$ & 3.386 & 2460382 & 1.13 & 4.689 & 1877220 & 1.21 \\
\hline
\end{tabular}

\section{Stability of drug solutions:}

Solution stability was estimated with standard concentration of $100 \mu \mathrm{g} / \mathrm{ml}$. The standard solution was injected and peak area values were recorded. This solution was then kept for $12 \mathrm{hrs}$ and injected in to HPLC and the peak areas were recorded. The same procedure was repeated at an interval of $12 \mathrm{hrs}$ until there was a significant change in the peak area value due to degradation (4\%). The $\%$ degradation was estimated by comparing with peak areas with the areas of freshly prepared solutions. The drug solutions were found to be stable for about $24 \mathrm{hrs}$ from the time of preparation. At the $36^{\text {th }}$ hour significant amount was degraded. Hence, both the drug solutions prepared in the mobile phase were stable up to $36^{\text {th }}$ hourfrom the time of their preparation. The results were given below in the Table.9.

TABLE.9. SOLUTION STABILITY DATA FOR ASPIRIN AND PRASUGREL

\begin{tabular}{lllll}
\hline $\begin{array}{l}\text { Time of Data } \\
\text { acquisition(hrs) }\end{array}$ & Aspirin & Prasugrel & \\
\cline { 2 - 5 } & Peak area & \% Recovery & Peak area & \% Recovery \\
\hline 0 & 4503473 & 100.6 & 3749114 & 100.2 \\
12 & 4464748 & 99.8 & 3733257 & 99.8 \\
24 & 4449862 & 99.54 & 3697907 & 98.9 \\
36 & 4221362 & 96 & 3419177 & 96 \\
\hline
\end{tabular}

CONCLUSION: The proposed method was found to be simple, rapid, precise, robust and accurate for the determination of Aspirin and Prasugrel in Tablet formulation. The sample recoveries from the formulation were in good agreement with the label claim, which suggests non-interference of formulation excipients in the estimation. The method was successfully validated in terms of 
linearity, precision, accuracy and robustness as per $\mathrm{ICH}$ guidelines. The method provides a linear response across a wide range of concentrations. Moreover, the method is fast with respect to analysis time, covering wide concentration ranges when compared to reported chromatographic techniques.

ACKNOWLEDGEMENTS: The authors are thankful to the management and authorities of Department of pharmaceutical Analysis, Care College of pharmacy for providing the necessities required for carrying out the present research work and also MSN laboratories, Hyderabad for providing the gift sample of Prasugrel.

\section{REFERENCES:}

1. Konari S.N, Jacob J.T.Development and Validation of RPHPLC method for the Simultaneous Estimation of Prasugrel and Aspirin in bulk and tablet dosage form. Inventi impact, pharmaceutical analysis and quality assurance.2013; 3: 52-58

2. Deepak Kumar Jain, Nilesh Jain, JitendraVerma, RP-HPLC Method for Simultaneous Estimation of Aspirin and Prasugrel in Binary Combination. International Journal of Pharmaceutical Sciences and Drug Research. 2012;4(3): 218221.

3. Ojikumar Lukram, MukundZarapkar, Chandan Kumar Jha, ShivajiParmar, Keshav S. Tomar, AmitHande. Electrospray ionization LC-MS/MS validated method for the determination of the active metabolite (R-138727) of prasugrel in human plasma and its application to a bioequivalence study. Drug Testing and Analysis. 2012; 4(2): 158-166.

4. SM Patel, CN Patel, VB Patel, Development and validation of spectrometric method for simultaneous estimation of Aspirin and Prasugrel in tablet dosage form. American Journal of Pharmaceutial Technology and Research. 2012;2(3): 819-827.

5. S. J. Parmar, B. A. Patel and A. P. Jain, Development and Validation of RP-HPLC Method for Prasugrel. Journal of Chemical and Pharmaceutical Research. 2012; 4(7): 33733376.

6. Bhavani V, Jameelunnisa B, Prakash M and Siva Rao T, Stability Indicating RP-UPLC method for the estimation of Prasugrel $\mathrm{Hcl}$ in pharmaceutical formulations. International Journal of Biology, Pharmacy and Allied Sciences, 2012; 1(7): 946-956.

7. Viralkumar J. Modi and Prashant L. Pingale, Development and validation of analytical method for estimation of prasugrel hydrochloride in bulk and in pharmaceutical formulations.
International journal of pharma and biosienes. 2012;3(4): 292298.

8. V. Krishnaiah and Y.V Rami Reddy. Development and validation of HPLC method for the simultaneous determination of aspirin. Journal of Chemical and Pharmaceutical Research. 2012; 4(3): 2349-2353.

9. Srikanth I, Sharma P, Vijayabharathi K, Raju M, Lakshmi Naik $M$ and Nagarjuna KA Validated Reverse phase HPLC method for the estimation of prasugrel hydrochloride in pharmaceutical dosage forms, Journal of Innovative trends in pharmaceutical sciences. 2011; 2(5): 140-148.

10. Mohammed Ishaq B, VanithaPrakash K and Krishna Mohan G, Development and validation of HPLC method for determination of prasugrel in bulk and its pharmaceutical formulation. Journal of chemical and pharmaceutical research. 2011; 3(4): 404-409.

11. Kishore Reddy Seerapu R, Venkateswara Rao A, Lavanya P, Pani Kumar AD, Ramakrishna K, Subba Reddy P.V, Development of validated RP-HPLC Method for the estimation of PrasugrelHcl in pure and pharmaceutical formulations, Journal of Pharmacy Research. 2011; 4(9): 3105-3107.

12. Ashok Kumar A, Anil Kumar A and GowriSankar D, Development, estimation and validation of prasugrel in bulk and in its pharmaceutical formulation by UV-Vis spectroscopic method. An International Journal of Advances in Pharmaceutical Sciences. 2011;2(1): 37-39.

13. Harshini B, SVR Alekhya, G Manasa, K Vanitha Prakash, Extractive Spectrophotometric Estimation Of Prasugrel In Pharmaceutical Formulation, Research Journal of Pharmaceutical, Biological and Chemical Sciences. 2011; 2(3): 426-429.

14. Ravi Pratap Pulla, Sastry BS, Rajendra Prasad Y and Appala Raju N, Estimation of prasugrel in tablet dosage form by RPHPLC, International Journal of Chemistry Research. 2011; 2(3): 34-36.

15. Borole TC, Mehendre R, Damle M.C, Bothara K.G, Development and validation of stability indicating HPTLC method for determination of prasugrel. Journal of Chemical and Pharmaceutical Research. 2010; 2(4): 907-913.

16. Borole TC, Mehendre R , Damle M.C, Bothara K.G, Development and validation of stability indicating HPTLC method for determination of prasugrel. Journal of Chemical and Pharmaceutical Research. 2010;2(4): 907-913.

17. Hassan H. Hammud, Fawzy A. El Yazbi, Mohamad E. Mahrous, Ghassan M. Sonji and Nada M. Sonji. Stabilityindicating Spectrofluorimetric and RP-HPLC methods for determination of Aspirin and Dipyridamole in combination. The open spectroscopy journal. 2008; 2: 19-28.

18. Ismail, $\mathrm{R}$ Rajavel, $\mathrm{M}$ Ganesh, $\mathrm{M}$ Jagadeeswaran, $\mathrm{K}$ Srinivasan, J Valarmathi and T Sivakumar. RP-HPLC method for simultaneous determination of Aspirin, Atorvastatin and Pioglitazone in capsule dosage form. Asian Journal of Research chemistry. 2008; 1(1): 40-42.

How to cite this article:

Vivek Sagar P, Samidha T, Vamshi Krishna M and Shobha Rani S: A Validated RP-HPLC Method for Simultaneous Estimation of Aspirin and Prasugrel in Tablet Dosage Form. Int J Pharm Sci Res 2014; 5(11): 4858-64.doi: 10.13040/IJPSR.0975-8232.5 (11).4858-64.

All @ 2014 are reserved by International Journal of Pharmaceutical Sciences and Research. This Journal licensed under a Creative Commons Attribution-NonCommercial-ShareAlike 3.0 Unported License.

This article can be downloaded to ANDROID OS based mobile. Scan QR Code using Code/Bar Scanner from your mobile. (Scanners are available on Google Playstore) 